\title{
Medical and social aspects of reproductive potential of youth
}

\author{
D. O. Kalynychenko
}

Educational and Scientific Institute of Physical Culture of

Sumy State Pedagogical University named after A. S. Makarenko

Paper received 03.11.17; Revised 09.11.17; Accepted for publication 10.11.17.

https://doi.org/10.31174/SEND-NT2017-148V16-14

\begin{abstract}
The article is dedicated to theoretical justification for methodology of research and assessment of reproductive potential of youth. It is proposed to use the characteristics of socio-economic conditions of vital activity, indices of physical and sexual development, personal qualities with the assessment of gender identification, reproductive attitudes, features of reproductive behavior, knowledge regarding reproductive health, the presence of chronic extragenital pathology and the degree of its compensation, the presence of gynecological pathology in the anamnesis and at the time of the examination.
\end{abstract}

Keywords: reproductive health, reproductive potential, reproductive attitudes, extragenital pathology, reproductive behavior.

Introduction. The sustainable development of society in any country substantially depends on the state of the nation's public health, its demographic prospect [22]. In the Concept of the State Program "Health - 2020: Ukrainian dimension" is specified that an unfavorable medical and demographic situation has developed in Ukraine recently, it indicates an unsatisfactory state of health of the population, which manifests itself in low birthrate, in comparison with high death rate, a negative natural increase of the population, and also high level of prevalence of chronic noninfectious diseases [9].

The priority factors of the unfavorable demographic situation are deterioration of social and economic conditions of vital activity, quality of the environment and, first of all, state of the reproductive health $(\mathrm{RH})$ of the population. However, in modern social and economic conditions of development of society it can be stated that the problem requires a comprehensive medical, social and psychological study [17, c. 12 - 23].

In the Constitution of WHO is proclaimed that "the enjoyment of the highest attainable standard of health is one of the fundamental rights of every human being without distinction of race, religion, political belief, economic or social condition". However, five decades after the adoption of this Constitution, it is increasingly admided that there are differences of the factors determining the level of health and a burden of diseases in women and men. In this regard, study of the dynamics of gender aspects of reproductive health to which the attention wasn't paid for a long time is of particular importance [2, 18].

A brief review of publications on this topic. The problem of $\mathrm{RH}$ of youth is the subject of scientific researches in various fields and a frequent topic of public hearings. The comprehensive medical and social evaluation of girls' RH was conducted in scientific researches by Yuriev V. K. (1998), was described in the scientific works of such scholars as Zhukova N.P., 2002; Ailamazian E. K., Bieliaieva T. V., 2003; Borysova Z. K., 2007; Surmach M. Yu., 2007; Koshel E. M., 2010; Buralkyna N. A., Uvarova E. V., 2010 - 2013; Znamenska M. A., Slabkyi H. O., 2012 - 2013; Shtohryn O. 2014; Kokh L. I., Burtseva H.A., 2016; Kurylo I. O., Aksonova S. Yu., Krimer B.O., 2016.

Numerous researches focus on clinical aspects of RH disorders (Hurkin, Yu. A., 2001; Zhuk S. I., 2006 - 2015; Bieliaieva N. V., 2009; Shabanova L. Yu., 2009; Levenets S. O., 2010; Pyrohova V. I., Tsolko O. R., Chaikivska E. F., 2011; Bariaieva O. Ye., 2012; Andriiets O. A., 2012;
Khardikov A. V., 2010; Podolskyi V. V., 2013; Zaporozhan V. M., 2014; Nachotova T. A., 2016). The works of specialists in preventive medicine represent significant informative interest (Medvedovska N. V., 2010; Berdnyk O. V., Dobrianska O. V., Skochko T. P., 2013; Biletska E. M., 1999 - 2016; Stus V. P., 2015; Kurylo I. O., Aksonova S. Yu., Krimer B. O., 2016; Tsiborovskyi O. M., 2015).

Scientists have studied the influence of environmental factors on RH (Pliaskina I. V., 2008; Alieksieiev V. B., 2009; P.M. Veropotvelian, 2009; Balter R.B., 2010; Andrieieva M. V., 2013; Onul N. M., 2015).

The issues of gender identity in various fields of science of other countries were investigated by scientists researchers such as Money J. (1955), Stoller R. (1964), Money J., Ehrhardt A., (1972), Bem S. L. (1974); Spens J. (1974 - 1993), Maccoby E., Jacklin K. (1974), Williams J. E., Best D. L., 1990. In native science, this issue was studied by: Kon I. S., Ilin Ye. P., Isaiev D. Ye., 2012; Kahan V. Ye., Dvorianchikov N. V., Nosov S. S., Salamova D. K., 2011; Iliasov F. N., 2013; Ivanova A. N., Samsonova T. V., 2015. In addition, gender norms, roles and relations in the context of reproductive health are constant issues in the action plan of the UN and WHO [20, 21, 23].

A new scientific direction has been formed today, it is called reproductology, which main subject of studying is the reproductive potential (RP), reproductive health, reproductive behavior $(\mathrm{RB})$ and reproductive process (Kulakov V.I. et al., 1993; Hurkin Yu.A., 1994, 1998; Frolova O.H. et al., 1995; Ahadzhanian N.A. et al., 1998). Yuriev V.K., 1998).

Despite numerous works on studying of reproductive health, such problems as scientific justification of the organization of the specialized medico-social help of student's youth, creation of system of monitoring of reproductive potential with taking into account features of the personality and quality of life of female contingent of early reproductive age can't be considered to be solved until recently.

The aim of the work was to theoretically justify a methodology of research and assessment of reproductive potential on the basis of the analysis of modern scientific literature on the issues of preservation of reproductive health of young people and to generalize approaches to interpretation of the concept "reproductive potential" with determination of structure and the system of indicators of his quantitative assessment.

Materials and methods. General scientific methods 
(generalization and systematization) of theoretical research of the problem of formation of reproductive potential among young people on the basis of system analysis were used during the course of the study. This article is a fragment of research work of Department of Medicobiological Fundamentals of Physical Culture of Educational and Scientific Institute of Physical Culture of Sumy State Pedagogical University named after A. S. Makarenko "Assessment of the reproductive potential of teenagers and youth with different types of gender identity" (state registration number 046 U007542 (09.2016 $-12.2020)$ ).

\section{Review of the publications on the topic.}

During the hearings in the Verkhovna Rada of Ukraine Committee on questions of health care on the subject: "About execution of the state program "Reproductive Health of the Nation" for the period up to 2015 and measures taken by the Ministry of Health of Ukraine in order to ensure the protection of reproductive health of the population ", Ella Libanova has noted that now women of the 90th year of birth when the birth rate was promptly reduced entered in the reproductive age. Therefore, the next 15 years can not be expected that the potential number of mothers will grow, that is, there is no reason to expect that the birth rate will increase. So the situation seems complicated. Rapid and irreversible processes of "ageing" of motherhood are added to it. The average age of a mother increases at the child's birth in European countries. In Ukraine, the average woman's age at the birth of the first child is 27.6 years. It is one of the lowest indicators in Europe so far [4].

Thus, girls of 18 - 24 years can be considered as the closest reserve of restoration of the population and a cohort of youth of active reproductive age [5, 16]. However, the state of their reproductive, physical health, deformation of social values adversely affect the realization of the opportunities of this reserve.

Evidence of the foregoing is the results of the analysis of statistical indicators of the state of health of teenage girls and girls of student age in recent years. In particular, extragenital pathology is registered in $72.4 \%$ of teenage girls, with a predominance of chronic forms $(47.0 \%)$, the frequency and severity of which increases with age ( from $71,4 \%$ at teenage age up to $73,4 \%$ in a cohort of student youth) and $44,3 \%$ and $49.4 \%$ of cases of encumbrance of somatic pathology respectively. More than a half of girls $(65,5 \%)$ have two or more nosologies. Among chronic forms of diseases the leading positions are taken by pathology of the musculoskeletal system $(31,6 \%)$, digestive system $(29,0 \%)$, organs of sight $(23,9 \%)$ and endocrine system $(18,8 \%)[1,7]$.

According to the results of scientific studies of national scientists, it is known that in the structure of chronic diseases of students prevailed diseases of the nervous system $(33,0 \%)$, digestive system $(31,9 \%)$ and blood circulation systems $(13,6 \%)$. Then followed the diseases of respiratory system $(9,8 \%)$, genitourinary system $(7,1 \%)$, endocrine system, disorders of metabolism $(2,9 \%)$, musculoskeletal system and connective tissue $(1,6 \%)$ and diseases of blood and hematopoietic organs and individual disorders involving the immune mechanism $(0,1 \%)$ [1].

According to literature, the share of absolutely healthy girls has decreased from $28.6 \%$ to $6.3 \%$ in recent years, and the general disease incidence of teenagers at the age of 15-17 years for the last 5 years has increased by $32,2 \%$. In modern conditions, the state of $\mathrm{RH}$ of youth is caused by faster puberty, early sexual activity and problems of early pregnancy, childbirth, abortion, and sexually transmitted infections connected with it.

The prevalence of gynecological diseases is increasing among girls. Thus, menstrual disorders have increased by 3.5 times at an early reproductive age in recent years, diseases of inflammatory character have increased by 5,4 times [11]. According to V.I. Pyrohova with co-authors the menstrual disorders occupy the first place in the structure of gynecological diseases of early reproductive age $(34-61 \%)$, the majority of which has functional origin [14].

O. P. Hnatko with co-authors define that the share of the girls suffering from gynecological diseases varies from $4.3 \%$ to $26.4 \%$. Analyzing the nature of the gynecological pathology of the female cohort of early reproductive age, it was found that abnormal uterine bleedings occur in $12.5 \%-14.3 \%$ of the examined girls; inflammatory diseases of the reproductive organs appear in 15.6 - $17.1 \%$; neuroendocrine syndromes occur in 6.3 $5.7 \%$; benign tumors appear in $6,3-5,7 \%$ and endometriosis is in $3,1-2,9 \%$; delayed sexual development occur in $3,1-2,9 \%$; polycystic ovary disease occur in $15.6 \%-17.1 \%$ of the examined [3].

As consequences of pathology of the reproductive sphere, and especially the disorders of the menstrual function in early fertile age, leads to infertility, obstetric pathology, perinatal losses, the frequency of which has increased by 1.7 times among young women over the past twenty years and according different authors is from $1.2 \%$ to $3.0 \%$ of the corresponding age group [10].

Studying the morbidity which is connected with pregnancy and childbirth of students, it was found that $44.2 \%$ of cases of complications are linked with the previous abortion, $31.2 \%$ are connected with the primary endocrine pathology, $28.7 \%$ are linked with chronic inflammatory processes of the genital organs, urogenital and viral infection [8].

Today, it is recognized that the risk factors for diseases and disorders of RH are: adverse lifestyle (chronic stress, low physical activity, uncontrolled sexual behavior, inadequate and ineffective use of contraceptives, inappropriate nutrition, non-compliance with a work-rest schedule, etc.); the use of harmful substances (tobacco, alcohol, drugs); influence of factors of the environment (environmental pollution); negative factors of the social environment (low living standards, unemployment, uncertainty in the future, etc.); negative hereditary factors; low level of access to medical care; imperfect system of consultation and information on $\mathrm{RH}$ and family planning [14].

It is well-known that birthrate is the result of reproductive behavior of people who differently estimate the degree of significance of socio-economic conditions of life and take the appropriate decision on the birth of children. The study of reproductive behavior and reproductive attitudes (needs) is an essential element for understanding and forecasting of tendencies of birthrates in the region, for developing concrete measures for 
effective demographic and family policy.

However, in the conditions of an adverse demographic situation, not only information about the state of health of the younger generation, which is characterized by statistical indicators, but also the future "reproductive potential", becomes of particular importance.

Today V. K. Yurev's opinion is fair and relevant. He stated that at existing extremely adverse indicators of morbidity, prevalence of diseases among the corresponding groups of the population, the use of the term "reproductive health" is not always correct, more appropriate concerning teenagers and young people is the use of the term "reproductive potential". The term "reproductive potential" should be interpreted as "the level of physical and mental state (the complex individual indicator reflecting the unity of the biological and social status of the individual), a condition that allows with the achievement of mental, sexual, biological and social maturity, under the corresponding biological, social conditions and actions of health care, to give birth and bring up healthy descendants and to provide balance of reproductive health" [18].

There are two fundamentally different authors' positions regarding the concept of reproductive potential of the population: the first position is conventionally called the "biological model" (reproductive potential is interpreted as the population's ability to reproduction and is reflected by the level of net reproduction rate (the number of the born girls and probability of their life before reproductive age) [15].

In this interpretation, the reproductive potential is considered to be completely realized if any pregnancy ends with childbirth (abortion is the most significant factor that reduces the reproductive potential of the population). However, "the biological model" limits the characteristic of reproductive potential and the effect of the main health-saving factors that have been allocated and grouped by the academician Yu. P. Lisitsyn (2010), namely: lifestyle, heredity, influence of the external environment, functioning of the health care.

The second position, substantiated by V. D. Yuriev and grounded by scientists of preventive medicine, more broadly characterizes the reproductive health and reproductive potential of the population as considers not only biological, but also its social component, combination of potential level of health and opportunities for its practical implementation with the use of the following criteria: socio-economic portrait of the family, psychological characteristics, reproductive attitudes (RA), reproductive behavior and awareness about reproductive health, the course of perinatal and postnatal periods, physical development, sexual development and degree of puberty, infectious index, the presence of chronic and extragenital pathology and the degree of its compensation, the presence of gynecological pathology in the anamnesis and at the time of the examination $[12,18]$.

From a position of studying of reproductive health as the basis of demographic safety of the country it is more justified the assessment of the level of the summarized reproductive potential of youth in the region.

First of all, RA are conventionally divided into two groups: firstly, there are the attitudes for the average number of children in the family, directed to achievement of the main result of reproductive behavior; and secondly, there are the attitudes for practices of contraception. In addition, the RA consist of three components: cognitive (informative), affective (emotional) and behavioural (stimulating). The entity of RA consists in interaction of all three components. The cognitive component reflects orrientation to this or that number of children, to intervals between their births, attitudes to a desirable sex of the child, to pregnancy and its happy completion. The emotional component of the reproductive attitude is made by the positive and negative feelings connected with the birth of this or that number of children. The behavioral component of the reproductive attitude characterizes the intensity of motivation to birth, the power or weakness of the reproductive attitude.

RA are implemented, first of all, under the influence of individual reproductive motives, the formation of which is influenced by economic, psychological, biological and social factors (reproductive motivations).

Economic reproductive motivations provide strengthening of welfare of family, receiving various privileges provided by the child's birth. Social reproductive motivations increase the social status of parents, heredity of the family. Psychological reproductive motivations are shown by requirements of meaning of life for children, love, respect, requirement of care of children, transfer of life experience, avoiding of loneliness and strengthening of the marriage relations [6; 13, c. 45 - 57].

Besides, the organism of each person has certain reproductive resources, that is an ability to change the balance to the positive side and thus to increase the reproductive potential $[15,18]$. An optimal case occurs when the negative impact of medical and social risk factors is minimized and the biological reserves of the organism are high. However, it is necessary to emphasize that characterisation of reproductive health from a position of assessment of reproductive potential is appropriate only by analyzing the characteristics of the population of child and fertile age [15].

Summary. Over the past years, scientific researches in the field of public health, clinical medicine and psychology have shown an increase in extragenital pathology and gynecological morbidity among women of early reproductive age, early sexual activity and risky forms of sexual behavior, consistently high rates of abortion and the incidence of sexually transmitted infections among young people.

The need for urgent measures to improve the reproductive health of girls requires intersectoral researches of reproductive potential in the field of health care, demography, sociology, psychology, pedagogy with the participation of interested ministries and departments, public structures, that will allow to develop effective proposals as to optimal socio-economic conditions, improvement of the system of rendering of specialized educational, preventive and medical care for youth.

For assessment of reproductive potential of persons of early reproductive age it is expedient to use a complex of the following criteria: the characteristics of socioeconomic conditions of vital activity, indices of physical and sexual development, personal qualities with the assessment of gender identification, reproductive 
attitudes, features of reproductive behavior, knowledge regarding reproductive health, the presence of chronic extragenital pathology and the degree of its compensation, the presence of gynecological pathology in the anamnesis and at the time of the examination.

\section{REFERENCES}

1. Buralkina N. A. Regional features of formation of reproductive system of teenage girls: author's abstract of thesis to the competition of scientific degree, doctor of medical sciences : spec. 14.01.01 - "Obstetrics and gynecology"/ N. A. Buralkina. - Moscow, 2013. - 40 p.

2. Inclusion of a gender problems in WHO's activities. WHO Gender Policy // World Health Organization, 2002. [Electronic resource]. - Access mode : http://apps.who.int/iris/bitstream/10665/99125/1/a78322_rus. pdf.

3. Hnatko O. P. Influence of somatic and gynecological pathology on reproductive health of teenage girls / O. P. Hnatko, A. I. Chubaty, L. L. Semeniuk // Obstetrics. Gynecology. Genetics. - 2016. - № 1. - P. $52-55$.

4. State Program "Reproductive Health of the Nation": Results and Perspectives (21 December 2016 ) // Female doctor. [Electronic resource]. - Access mode : http://z1.com.ua/ru/newsid/2158.

5. Health of girls and women // WHO newsletter №334 (September 2013). - [Electronic resource]. - Access mode : http://www.who.int/mediacentre/factsheets/fs334/ru/.

6. Iliasov F. N. Need for children and reproductive behavior / F. N. Iliasov // Monitoring of public opinion. - 2013. - №1 . - P. 168-177.

7. Kalynychenko I. O. Dynamics of indicators of the state of children's health (regional aspect) / I. O. Kalynychenko // Ukraine. Health of the nation. - 2009. - № 3 (11). - P. 47 55.

8. Kasianova N. V. Assessment of state of reproductive health of students of Donetsk Railway Transport Institute / N. V. Kasianova, I. V. Podoliaka // Medicine of transport of Ukraine. - 2008. - №1. - P. 77 - 79.

9. The Concept of the State Program "Health - 2020: Ukrainian dimension" : [Electronic resource]. - Access mode : http://www.kmu.gov.ua/control/uk/cardnpd?docid=24471778 7.

10. Nachotova T. A. Secondary amenorrhea in teenage girls clinical and hormonal-metabolic aspects, pathogenesis, diagnosis and treatment) : author's abstract of thesis to the competition of scientific degree, doctor of medical sciences : spec. 14. 01.01 "Obstetrics and gynecology" / T. A. Nachotova. - Charkiw, 2016. - 40 p.

11. Features of the state of health of modern student youth and ways of its preservation / Serheta I.V., Dunets I.L., Stoian N.V., Panchuk O.Yu. et al. // VII International Congress on Integrative Anthropology (Vinnytsia, 17 - 18 October 2013). - Vinnytsia, 2013. - P. $145-146$.

12. Polka N. S. Approaches to formation of gender-oriented programs in the field of health protection of children and teenagers. / N. S. Polka, O. V. Berdnyk, O. V. Dobrianskaia //
Environment and health. - 2015. - № 2. - P. 20 - 23.

13. Psychological and psychophysiological aspects of reproductive health: Scientific and methodical manual / M.-L. A. Chepa, N. V. Slobodianyk, S. I. Boltivets, N. D. Volodarska, O. Ya. Slobodianyk. Foreword by academician S. D. Maksymenko. - K. : Milenium, 2005 - P. $45-57$.

14. Reproductive realities of modern teenage girls / V. I. Pyrohova, O. R. Tsolko, E. F. Chaikivska, Yu. V. Masliuk // Taurian medical and biological bulletin. - 2011. - T. 14, № 3 (p. 2). - T. $153-157$.

15. Surmach M. Yu. Reproductive health and reproductive potential: research and evaluation methodology / M. Yu. Surmach // Medical news. - 2007. - №3. - P. 40 - 45.

16. Shyian Olena. Youth as a target group of state educational policy on ensuring a healthy lifestyle / Olena Shyian // Bulletin of the National Academy of Public Administration under the President of Ukraine. - 2009. - № 3. - P. 223 229.

17. Annual report on the state of health of the population, sanitary and epidemiological situation and results of activity of the health care system of Ukraine. 2015 / edited by Shafranskyi V. V.; Ministry of Healthcare of Ukraine, State Institution "Ukrainian Institute for Strategic Studies of the Ministry of Healthcare of Ukraine". - K., 2016. - P. 12 - 23.

18. Yurev V. K. Methodology of assessment and condition of reproductive potential of girls and young women / V. K. Yurev // Problems of social hygiene, health care and history of medicine. - №4. - 2000. - P. 3 - 5.

19. Development and Gender, Issue 5: Approaches to institutionalizing gender, Gender in Brief, Institute of Development Studies, University of Sussex, England, May 1997

http://apps.who.int/iris/bitstream/10665/99125/1/a78322_rus. pdf.

20. Improving Adolescent Sexual and Reproductive Health: A Systematic Review of Potential Interventions / Rehana A. Salam, Anadil Faqqah, Nida Sajjad, Zohra S. Lassi, et al. // The Journal of Adolescent Health. - 2016. - Oct; 59 (4 Suppl): P. $11-28$.

21. UNFPA strategy on adolescents and youth. Towards realizing the full potential of adolescents and youth // Access mode : https://www.unfpa.org/sites/default/files/resourcepdf/UNFPA\%20Adolescents\%20and\%20Youth\%20Strategy. pdf.

22. Patton G. Evidence and Evidence Gaps in Adolescent Health / G. Patton, M. Temmerman // The Journal of Adolescent Health. - 2016. - Oct; 59 (4 Suppl) : P. 1 - 3.

23. Women and health: today`s evidence tomorrow`s agenda // WHO report.World Health Organization, 2009. - P.39.

\section{Медико - социальные аспекты репродуктивного потенциала молодежи \\ Д. О. Калиниченко}

Аннотация. В статье выполнено теоретическое обоснование методологии исследования и оценки репродуктивного потенциала молодёжи. Предлагается использовать характеристики социально - экономических условий жизнедеятельности, показатели физического и полового развития, личностные качества с оценкой гендерной идентификации, репродуктивные установки, особенности репродуктивного поведения, информированность в вопросах репродуктивного здоровья, наличие хронической экстрагенитальной патологии и степень ее компенсации, наличие гинекологической патологии в анамнезе и на момент обследования.

Ключевые слова: репродуктивное здоровье, репродуктивный потенциал, репродуктивные установки, экстрагенитальная патология, репродуктивное поведение. 